\title{
Wykorzystanie crowdfundingu w finansowaniu działalności gospodarczej
}

\begin{abstract}
Angelika Kędzierska-Szczepaniak*
Celem autorki jest prezentacja i analiza poszczególnych modeli crowdfundingu z uwzględnieniem roli, jaka moga odegrać w finansowaniu działalności gospodarczej. Finansowanie spotecznościowe z roku na rok staje się coraz częściej wykorzystywana forma finansowania. Jest to szansa zarówno dla przedsiębiorstw dopiero rozpoczynajacych swoja działalność, akcji charytatywnych, jak i osób fizycznych, które maja pomysty biznesowe, ale brakuje im środków na ich realizacje. Polscy przedsiębiorcy też coraz cześciej z niego korzystaja, rośnie liczba $i$ wartość transakcji, ale również liczba portali crowdfundingowych. Dostosowanie rozwiazań prawnych do potrzeb rynku prawdopodobnie spowoduje jeszcze większe zainteresowanie taka forma finansowania.
\end{abstract}

Słowa kluczowe: finansowanie społecznościowe, przedsiębiorcy, inwestycje, finansowanie MMSP.

Nadesłany: 29.05.2016 | Zaakceptowany do druku: 23.09.2016

\section{The use of crowdfunding in the financing of economic activity}

The aim of the article is to present and analyze the different models of crowdfunding, including the role they can play in the financing of economic activity. Crowdfunding is becoming increasingly used form of financing from one year to another. This is an opportunity for entrepreneurs just starting their business, charities, and individuals who have business ideas but lack of the funds for their implementation. Polish entrepreneurs are also increasingly using it. Not only the number and value of transactions but also the number of crowdfunding platforms is growing up. Adapting legal solutions to the needs of the market is likely to cause even greater interest in this form of financing.

Keywords: crowdfunding, start-ups financing, investment, entrepreneur, small business finance.

Submitted: 29.05.2016 | Accepted: 23.09.2016

JEL: G00, G02, G24, G32, L21

\footnotetext{
Dr Angelika Kędzierska-Szczepaniak - Wydział Zarządzania, Katedra Finansów i Ryzyka Finansowego, Uniwersytet Gdański.

Adres do korespondencji: Wydział Zarządzania, Katedra Finansów i Ryzyka Finansowego, Uniwersytet Gdański, ul. Armii Krajowej 101, p.129, 81-824 Sopot; e-mail: a.szczepaniak@ug.edu.pl.
} 


\section{Wprowadzenie}

Jednym z większych problemów, z którym muszą zmierzyć się przedsiębiorstwa na początku swojej działalności gospodarczej, jest pozyskanie kapitału. Z jednej strony można sądzić, że źródeł finansowania jest wiele, $z$ drugiej zaś dostęp do większości $\mathrm{z}$ nich jest ograniczony dla przedsiębiorstw, które stoją na początku swojej drogi, nie mają historii, zagwarantowanych kontraktów i stabilnych przychodów. Jednym z możliwych do wykorzystania źródeł finansowania staje się tzw. finansowanie 3F (ang. family, friends, foolhardly investors - rodzina, przyjaciele i nieroztropn inwestorzy) (O'Gorman, 2006). Wiadomo jednak, że źródła te są ograniczone - środki pozyskane w rodzinie moga okazać się niewystarczające, przyjaciele również mogą nie posiadać wymaganego kapitału lub zwyczajnie nie chcieć wspólfinansować ryzykownego przedsięwzięcia, a inwestorów trudno jest znaleźć. Finansowanie działalności nowo powstających przedsiębiorstw może odbywać się również przy wykorzystaniu środków pochodzących z programów unijnych (w poprzednich latach przede wszystkim z programu Innowacyjna Gospodarka) i funduszy pożyczkowych, np. Jeremie. Przedsiębiorcy mogą starać się również o środki z funduszy VC (ang. venture capital) czy od aniołów biznesu (ang. BA - business angels). Dodatkową alternatywa staje się też coraz bardziej popularny na całym świecie crowdfunding 1 , przetlumaczony na język polski jako „finansowanie społecznościowe".

Celem autorki jest prezentacja i analiza poszczególnych modeli crowdfundingu z uwzględnieniem roli, jaką mogą odegrać w finansowaniu działalności gospodarczej. W artykule wykorzystane zostana informacje pochodzące z Komisji Europejskiej, Polskiej Agencji Rozwoju Przedsiębiorczości, platform crowdfundingowych oraz zagranicznej i krajowej literatury.

\section{Rodzaje finansowania społecznościowego}

Pozyskanie kapitału, czyli funduszy powierzonych przedsiębiorstwu przez jego właścicieli i wierzycieli (Duliniec, 2001), to jedna z najważniejszych kwestii, z którymi musi poradzić sobie osoba prowadząca (lub pragnąca prowadzić) działalność gospodar- czą, szczególnie we wczesnej fazie rozwoju. Działalność przedsiębiorstwa (zarówno bieżąca, jak i rozwojowa) finansowana jest $\mathrm{z}$ reguły kapitałem własnym i obcym (Szyszko, 2000). Środki pozyskane poprzez crowdfunding, w zależności od modelu finansowania, który został wykorzystany, mogą przyjmować cechy kapitału zarówno własnego, jak i obcego.

Crowdfunding to otwarte zaproszenie do wsparcia finansowego określonego pomysłu przy wykorzystaniu platformy internetowej. Wsparcie to może przybierać formę darowizny lub gwarantować finasującemu określona korzyść (Kleeman i in., 2008, Cunningham, 2012). Każdorazowo cel projektu, przeznaczenie środków i efekty wydatkowania są jasno określone (Kozioł-Nadolna, 2015). Dzięki internetowej formie przekazu pomysłodawca trafia ze swoim projektem do wielu podmiotów, które mogą być potencjalnie zainteresowane ulokowaniem środków w jego przedsięwzięciu. Tym, co odróżnia crowdfunding, jest konieczność wykorzystania Internetu do pozyskania kapitału. W tym celu tworzone są specjalne platformy internetowe, których głównym zadaniem jest pośredniczenie pomiędzy przedsiębiorcami-pomysłodawcami, którzy poszukują kapitału a podmiotami, które tym kapitałem dysponują (darczyńcami, inwestorami, pożyczkodawcami). Niejednokrotnie platformy crowdfundingowe wspomagają również strony w zakresie obsługi prawnej, marketingowej, technicznej i organizacyjnej.

Wynikiem skierowania oferty do społeczeństwa przez portal internetowy jest to, że projekt angażuje zdecydowanie więcej uczestników niż tradycyjne źródła finansowania (Belleflamme, Lambert i Schwienbacher, 2014). Dostawcy kapitału mogą oczekiwać określonych świadczeń w zamian za powierzone środki. W przeciwieństwie do innych metod finansowania, nie muszą one jednak przyjmować formy płatności pieniężnej. Korzyścią, którą otrzymuje dostawca kapitału, może być możliwość zakupu produktu końcowego w przedsprzedaży (np. płyta, gra, książka), zakupu po promocyjnej cenie, zakupu produktu z autografem czy też nagroda w postaci darmowej płyty czy biletu na koncert (Król, 2011).

W zależności od tego, jaką korzyść otrzyma dostawca kapitału, można wyróżnić kilka form crowdfundingu. Ich podział nie jest jednolity - Belleflamme (2014) 
Rysunek 1. Rodzaje crowdfundingu

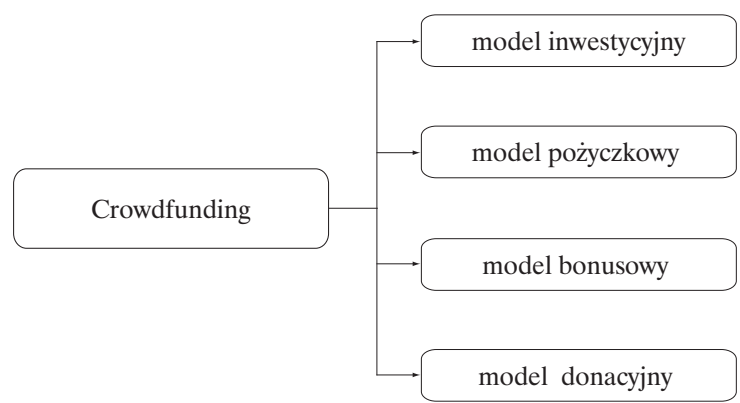

Źródło: opracowanie własne na podstawie Lambert i Schwienbacher (2010); Dziuba (2012).

wyróżnia tylko dwie formy pozyskania środków na sfinansowanie przedsięwzięcia - przedsprzedaż i udziały w zyskach, natomiast Hemer (2011) wymienia ich aż siedem: dotacje, sponsoring, przedsprzedaż, składki członkowskie, kredytowanie, pożyczki i udziały w zyskach. Podział na cztery główne rodzaje (rysunek 1) i ich dalsze podtypy rozróżniają Lambert, Schwienbacher (2010), Kuppuswamy (2013) oraz Mollick (2014).

Dwa pierwsze modelu crowdfundingowego dotyczą finansowania zwrotnego, w którym potencjalny dostawca kapitału otrzymuje określony zwrot $\mathrm{z}$ zainwestowanego kapitału. Model inwestycyjny (czasem można spotkać sie z określeniem - udziałowy; ang. crowdinvestment/equity crowdfunding) dotyczy sytuacji, w której po zainwestowaniu środków w projekt inwestorzy oczekują udziału w zyskach. Dostawca kapitału staje się współwłaścicielem przedsiębiorstwa proporcjonalnie do swojego wkładu. Druga forma, tj. model pożyczkowy (ang. lending), polega na tym, że finansujący otrzymują zwrot zainwestowanego kapitału wraz $\mathrm{z}$ odsetkami. $\mathrm{Z}$ jednej strony przypomina to klasyczne pożyczki, z drugiej jest jednak zdecydowanie łatwiejsze do pozyskania i pochodzi od wielu różnych pożyczkodawców. Platforma crowdfundingowa pełni funkcje pośrednika między dostawcami kapitału a podmiotami, które potrzebują finansowego wsparcia. Inaczej niż w przypadku banków, nie gromadzi aktywów, nie tworzy depozytów i nie zapewnia dostawcom kapitału takich samych gwarancji jak banki. Ponadto, inaczej niż w przypadku banków, platformy pośredniczące pozwalają kapitałodawcom na wybór projektu, który chcą współfinan- sować i ewentualnie wybór, jak wysokie ryzyko chca podjąć (Murray, 2015).

Dwa kolejne modele dotyczą sytuacji, w której dostawcy kapitału nie oczekują zwrotu z inwestycji w rozumieniu finansowym. W przypadku modelu bonusowego, tłumaczonego również na jezyk polski jako oparty na nagrodach (ang. reward crowdfunding), finansujący w zamian za przekazane środki otrzymują upominki, które mogą mieć znaczenie wymierne (np. bilet, płyta, gra czy też możliwość zakupu finalnego produktu w promocyjnie cenie, $\mathrm{z}$ określona zniżką lub w formule przedsprzedaży) lub czysto symboliczne, np. autograf, zdjęcie artysty. Warto jednak podkreślić, że często ta przekazywana nagroda ma niższa wartość niż wkład finansowy w przedsięwzięcie. Takie wsparcie może w szczególności znaleźć uzasadnienie $\mathrm{w}$ produkcji towaru czy produktu lub świadczeniu usługi, na której bardzo zależy potencjalnym klientom (przykładowo organizacja koncertu muzycznego, wydanie gry komputerowej).

Model donacyjny (tłumaczony się również jako dotacyjny; ang. donation/non-reward) polega przede wszystkim na wspieraniu różnego rodzaju akcji charytatywnych, które służą pomocą ludziom potrzebującym (ze względu na chorobę, trudną sytuację materialną itp.) lub są realizowane dla dobra publicznego. Dla przedsiębiorstw znaczenie modelu donacyjnego $\mathrm{w}$ finansowaniu ich podstawowej działalności jest minimalne, jednak ze względu na jego wielkość i rolę w rozwoju crowdfundingu ten model jest ważnym elementem całego rynku finansowania społecznościowego.

Według podziału stosowanego w zestawieniu Crowdfunding Industry Report (2013) wyróżnia się jeszcze model oparty 
na tantiemach (ang. royalty financing lub revenue-based financing) i hybrydowy. Pierwszy z nich dotyczy sytuacji, w której finansujący mają określony udział w przychodach z działalności spółki do osiągnięcia założonego z góry pułapu. Model hybrydowy, nazywany również mieszanym, polega na połączeniu przynajmniej dwóch form crowdfundingu równocześnie.

\section{Rozwój finansowania społecznościowego na świecie}

Dynamiczny rozwój crowdfundingu na świecie obserwuje się od 2008 roku. Podobny sposób finansowania znany był jednak już w 1885 roku, kiedy naród francuski ufundował dla narodu amerykańskiego Statuę Wolności. Joseph Pulitzer ogłosił zbiórkę pieniędzy na budowę podstawy dla Statuy Wolności w gazecie New York World (Best i Neiss, 2014). W zamian za datki obiecywał wydrukowanie nazwiska każdego z darczyńców. Akcja Pulitzera spotkała się z ogromnym zainteresowaniem Amerykanów. Pomimo upływu lat przesłanki, które wówczas zachęciły społeczeństwo do sfinansowania projektu są w dużej mierze takie same jak obecnie. Ludzie bardzo często chcą uczestniczyć w czymś ważnym, stać się częścią historii.

Zainteresowanie finansowaniem społecznościowym wzrosło dopiero po wybuchu kryzysu finansowego, który w dużej mierze ograniczył dostęp do kapitału nowym przedsiębiorcom. Banki nie udzielały kredytów inwestycyjnych nawet zyskownym firmom, które odniosły sukces (Kleeman, Voss i Rieder, 2008). Wydarzeniem, które wpłynęło na rozpowszechnienie informacji o finansowaniu społecznościowym, była zbiórka środków na zakończoną sukcesem kampanię prezydencką Baracka Obamy, realizowaną w 2008 roku (Kappel, 2009). Poprzez stronę internetową barakobama.com zgromadził on $600 \mathrm{mln}$ dolarów od ponad 3 milionów darczyńców, którzy wpłacali średnio po 86 dolarów amerykańskich (http://www.danmarom.com/, dostęp 20.10.2015). Cztery lata później, kiedy Barack Obama starał się o reelekcję, kapitał na finansowanie kampanii również pozyskał w dużej mierze od społeczeństwa amerykańskiego. Uzyskał wtedy $631 \mathrm{mln}$ dolarów, w tym 214 mln od tzw. drobnych darczyńców (http://www.crowd101.com/ dostęp z dnia 8.03.2016).
Znaczenie finansowania społecznościowego wzrastało wraz z rozwojem Internetu i różnego rodzaju platform społecznościowych. Pierwsza platforma internetowa, ArtsistShare, służąca pozyskiwaniu środków finansowych na wydanie płyt od fanów, została założona w 2003 roku przez Briana Camelio, bostońskiego muzyka i informatyka (Freedman i Nutting, 2015). W 2005 roku została założona organizacja Kiva, której zadaniem było pośredniczenie i przekazywanie mikropożyczek przedsiębiorcom w krajach rozwijających się, pochodzących od mieszkańców Stanów Zjednoczonych (Best i Neiss, 2014).

Już po sukcesie Baracka Obamy, w 2009 roku rozpoczęła działalność jedna z największych platform crowdfundingowych na świecie - Kickstarter. Platforma w początkowej fazie swojej działalności służyła przede wszystkim do odkrywania i finansowania talentów muzycznych (www.kickstarter.com). Założyciel sam był artystą i wiedział, jak trudne jest przebicie się i zdobycie środków na sfinansowanie płyty. Na platformie dał muzykom, artystom możliwość zaprezentowania się, aby fani mogli wspierać finansowo ich działania. W zamian za to otrzymywali płytę, koszulkę, plakat z podpisem. Otwarcie Kickstartera było niejako początkiem istnienia tzw. mikropatronów sztuki. Do rozwoju crowdfundingu przyczynił się również rozwój mediów społecznościowych, takich jak MySpace, Facebook, Instagram czy Twitter, gdzie ludzie mogli wymieniać informacje, przekazywać sobie pomysły, zachęcać się nawzajem do podejmowania pewnych działań, niejednokrotnie bez konieczności poznawania się osobiście.

Zainteresowanie crowdfundingiem wzrasta $\mathrm{z}$ roku na rok, co przedstawiono w tabeli 1. W 2011 roku wartość transakcji wzrosła o $64 \%$ w porównaniu z rokiem 2010 , natomiast w 2012 roku odnotowano wzrost wartości transakcji na świecie o blisko $81 \%$ w stosunku do roku 2011 i o $164 \%$ w porównaniu z rokiem 2010. Największy procentowy wzrost, wynoszący ponad $165 \%$, miał miejsce w roku 2014, jednakże wartościowo rekordowy był rok 2015, kiedy wartość transakcji wzrosła o ponad 18,2 mld USD do 34,4 mld USD (Crowdfunding Industry Report, 2015).

Najwięcej transakcji, aż 72\% ogółu, dokonywanych jest na rynku amerykańskim. Jednak najbardziej dynamiczny rozwój transkacji crowdfundingowych ma 
Tabela 1. Wartość transakcji crowdfundingowych na świecie w latach 2010-2015

\begin{tabular}{|c|c|c|}
\hline Rok & $\begin{array}{c}\text { Wartość } \\
\text { (mld USD) }\end{array}$ & $\begin{array}{c}\text { Wzrost } \\
\text { procentowy } \\
\text { rok do roku (\%) }\end{array}$ \\
\hline 2010 & 0,90 & - \\
\hline 2011 & 1,48 & 64,40 \\
\hline 2012 & 2,67 & 80,40 \\
\hline 2013 & 6,10 & 128,50 \\
\hline 2014 & 16,20 & 165,60 \\
\hline 2015 & 34,40 & 112,34 \\
\hline
\end{tabular}

Źródło: opracowanie własne na podstawie Crowdfunding Industry Report (2013; 2015).

miejsce w Azji. W 2013 roku Chiny zajmowały drugie (po Stanach Zjednoczonych) miejsce na świecie, jeżeli chodzi o liczbe zarejestrowanych transakcji udziałowych lub pożyczkowych. W 2014 roku wartość całkowita finansowania społecznościowego w Azji wzrosła aż o 320\% w porównaniu z rokiem 2013 i tym samym Azja stała się drugim kontynentem po Ameryce Północnej z największą wartością transakcji (wyprzedzając jednocześnie Europę). Jest to najbardziej spektakularny wzrost w 2014 roku. Dane dotyczące wartości transakcji przedstawiono w tabeli 2.

Blisko $80 \%$ wszystkich realizowanych transakcji przypada na Amerykę Północną i Azję. Udział Europy w światowym finansowaniu społecznościowym wynosi niewiele ponad $20 \%$. Najmniejszy udział w rynku crowdfundingowym mają Oceania i Afryka - pierwsza ze względu na to, iż jest to rejon geograficzny, w którego skład wchodzi najmniejszy kontynent - Australia, drugi ze względu na poziom rozwoju gospodarczego. Strukturę rynku finansowania społecznościowego kształtuje przede wszystkim rynek Stanów Zjednoczonych, Azji (głównie Chin) i Europy (głównie Wielkiej Brytanii).

Wykorzystanie poszczególnych modeli crowdfundingowych na świecie ulega zmianom. Początkowo przedsięwzięcia dotyczyły przede wszystkim akcji charytatywnych i pasjonackich. Najmniejsze znaczenie miał model inwestycyjny. Wynika to przede wszystkim z braku precyzyjnych uregulowań prawnych związanych z tym źródłem finansowania w wielu krajach i tym samym z jego nieobecnościa na rynkach. Modele, w których dostawcy kapitału nie oczekują wymiernych korzyści finansowych (donacyjny i oparty na nagrodach) stanowiły do 2012 roku większość wszystkich inicjatyw finansowania społecznościowego. Ma to związek z początkami rozwoju crowdfundingu, które dotyczyły przede wszystkim akcji charytatywnych, organizowanych dla dobra publicznego, gdzie darczyńcy nie oczekiwali żadnych świadczeń w zamian, zadowalał ich sam fakt realizacji i powodzenia przedsięwzięcia. W 2010 roku donacje stanowiły prawie $55 \%$ wszystkich tego typu transakcji (tabela 3).

Wraz z rozwojem rynku na znaczeniu zaczął zyskiwać przede wszystkim model pożyczkowy crowdfundingu i to on jest obecnie najważniejszym filarem finansowania społecznościowego na świecie, sta-

Tabela 2. Wartość transakcji crowdfundingowych na świecie w 2014 roku

\begin{tabular}{|l|c|c|}
\hline \multicolumn{1}{|c|}{ Kontynent } & Wartość (mld USD) & Wzrost w porównaniu z rokiem 2013 (\%) \\
\hline Ameryka Północna & 9,46 & 145 \\
\hline Azja & 3,40 & 320 \\
\hline Europa & 3,26 & 141 \\
\hline Ameryka Południowa & 57,20 & 167 \\
\hline Oceania & 43,20 & 59 \\
\hline Afryka & 12,00 & 101 \\
\hline Razem & $\mathbf{1 6 , 2 3}$ & $\mathbf{1 2 9}$ \\
\hline
\end{tabular}

Źródło: opracowanie własne na podstawie Pais (2015). 
Tabela 3. Struktura procentowa udziału poszczególnych modeli w crowdfundingu ogółem w latach 2010-2015 (w \%)

\begin{tabular}{|l|r|r|r|r|r|r|}
\hline \multicolumn{1}{|c|}{ Model } & $\mathbf{2 0 1 0}$ & $\mathbf{2 0 1 1}$ & $\mathbf{2 0 1 2}$ & $\mathbf{2 0 1 3}$ & $\mathbf{2 0 1 4}$ & $\mathbf{2 0 1 5}$ \\
\hline Donacyjny & 54,65 & 48,93 & 36,81 & 22,05 & 11,96 & 8,28 \\
\hline Bonusowy & 1,86 & 4,45 & 14,41 & 11,95 & 8,20 & 7,79 \\
\hline Inwestycyjny & 5,92 & 6,44 & 4,35 & 6,50 & 6,84 & 7,44 \\
\hline Pożyczkowy & 37,57 & 40,18 & 43,97 & 56,61 & 68,31 & 72,95 \\
\hline Mieszany & 0,00 & 0,00 & 0,47 & 2,90 & 4,69 & 3,53 \\
\hline Razem & $\mathbf{1 0 0 , 0 0}$ & $\mathbf{1 0 0 , 0 0}$ & $\mathbf{1 0 0 , 0 0}$ & $\mathbf{1 0 0 , 0 0}$ & $\mathbf{1 0 0 , 0 0}$ & $\mathbf{1 0 0 , 0 0}$ \\
\hline
\end{tabular}

Źródło: opracowanie własne na podstawie: Crowdfunding Industry Report 2013 i 2015 (Massomedia) i http://www.biia.com/crowdfunding-peer-to-peer-lending-expect-to-triple-in-2015 (24.02.2016).

nowiąc w 2015 roku blisko 73\% wszystkich transakcji. Pomimo malejącego udziału finansowania opartego na nagrodach i donacjach, nadal stanowią one ważny element crowdfundingu. Duże koncerny światowe niejednokrotnie biorą aktywny udział w pozyskiwaniu ta drogą środków finansowych, które mają wspierać ochronę środowiska, poprawe warunków bytowych ludności czy służyć realizacji innych celów społecznych. Koncerny te nie wykorzystują pozyskanego kapitału do własnej działal- ności, a udział w takich przedsięwzięciach ma dla nich przede wszystkim wymiar wizerunkowy. Przykładem może być firma Coca Cola Company, która zbierała środki na budowę studni w rejonach ubogich w wode w Meksyku. Innym przykład to Microsoft, który zbierał środki na udoskonalenie swojego oprogramowania dla potrzeb małych i średnich przedsiębiorstw (Bedigian, 2014).

Niewielkie zainteresowanie przedsiębiorców dotyczy modelu inwestycyjnego. Ekonomiści uważają, że jest on niedosza-

Tabela 4. Wybrane przedsięwzięcia finansowane $w$ formie crowdfundingu w latach 2012-2015

\begin{tabular}{|l|l|l|l|l|l|}
\hline & \multicolumn{1}{|c|}{ Firma } & \multicolumn{1}{|c|}{ Przedsięwziecie } & \multicolumn{1}{c|}{ Platforma } & \multicolumn{1}{c|}{$\begin{array}{c}\text { wartość } \\
\text { w USD }\end{array}$} & $\begin{array}{c}\text { Model } \\
\text { crowdfundingu }\end{array}$ \\
\hline 1. & Pebble & $\begin{array}{l}\text { Smartwatch/inteligenty } \\
\text { zegarek }\end{array}$ & Kickstarter.com & 20338986 & bonusowy \\
\hline 2. & Ouya & Konsola do gier & Kickstarter.com & 8500000 & bonusowy \\
\hline 3. & Pono & $\begin{array}{l}\text { Przenośny cyfrowy odtwarzacz } \\
\text { multimedialny }\end{array}$ & Kickstarter.com & 6000000 & bonusowy \\
\hline 4. & Bitvore & Analizator danych & Fundable.com & 4500000 & inwestycyjny \\
\hline 5. & $\begin{array}{l}\text { Oculus } \\
\text { VR }\end{array}$ & Zestaw słuchawkowy & Kickstarter.com & 2437429 & bonusowy \\
\hline 6. & $\begin{array}{l}\text { Rayton } \\
\text { Solar Inc. }\end{array}$ & Solar & Fundable.com & 2830000 & inwestycyjny \\
\hline 7. & $\begin{array}{l}\text { Mass } \\
\text { Fidelity }\end{array}$ & $\begin{array}{l}\text { Bezprzewodowy głośnik - } \\
\text { Core Wireless Speaker }\end{array}$ & Indiegogo.com & 1516506 & bonusowy \\
\hline 8. & POND & $\begin{array}{l}\text { Ladowarka bezprzewodowa } \\
\text { POND }\end{array}$ & Fundable.com & 1000000 & inwestycyjny \\
\hline
\end{tabular}

Źródło: opracowanie własne. 
cowany i w kolejnych latach można spodziewać się wzrostu znaczenia właśnie tej formy crowdfundingu. Według Mollicka (2014) model inwestycyjny może zmienić całkowicie rynek finansowania zalążkowego na świecie i stanowić poważną konkurencję dla aniołów biznesu czy też funduszy private equity. W tabeli 4 przedstawiono przykładowe przedsięwzięcia zrealizowane w formule finansowania społecznościowego na świecie.

Pebble to firma, która już kilkakrotnie pozyskała środki na sfinansowanie produktów (zegarki) poprzez finansowanie społecznościowe. W 2012 roku uzyskała dzięki zbiórce na platformie Kickstarter kwote ponad $10 \mathrm{mln}$ USD, podczas gdy w 2015 roku starała się zebrać 500 tys. USD, a zainteresowani darczyńcy wpłacili ponad $20 \mathrm{mln}$ USD. Zanim firma zdecydowała sie na pozyskanie kapitału w formule finansowania społecznościowego, próbowała zainteresować swoim pomysłem potencjalnych inwestorów, jednak nie byli oni chętni do angażowania kapitału w to przedsięwzięcie.

\section{Finansowanie społecznościowe w Polsce}

Zainteresowanie crowdfundingiem w Polsce systematycznie wzrasta. Za pierwszą zbiórkę zorganizowaną w formule finansowania społecznościowego, choć bez udziału platformy crowdfundingowej, można uznać kampanię zorganizowana na wyprodukowanie krótkometrażowego filmu Wszystko przez absolwenta Wyższej Szkoły Filmowej (wszystko.net, dostęp $\mathrm{z}$ dnia 12.03.2016). Zwrócił się on $\mathrm{z}$ apelem do społeczności internetowej o wsparcie projektu, w zamian oferujac umieszczenie nazwiska darczyńcy w napisach końcowych i kopie filmu na DVD (po zakończeniu jej dystrybucji w kinach). Przedsięwzięcie wsparło 688 osób, od których pozyskano łącznie ponad 28 tysiecy złotych. Nie była to kwota wystarczająca na zrealizowanie pomysłu, jednak dzięki tym środkom, nagrodzie uzyskanej przez reżysera w Polskim Instytucie Sztuki Filmowej i środkom własnym udało się w 2007 roku rozpocząć produkcję filmu, który miał premierę w 2009 roku.

Pierwszą platformą crowdfundingową w Polsce jest istniejąca od 2007 roku wytwórnia muzyczna MegaTotal.pl. Jest to portal poświęcony muzykom, który zrealizował już ponad 80 muzycznych projektów, w tym wydał 60 płyt o łącznym nakładzie przekraczającym 50 tysięcy egzemplarzy. Według danych na 2016 portal ten ma już ponad 100 tys. fanów i wykorzystuje go około 5000 artystów (www.megatotal.pl, dostęp z dnia 20.02.2016).

Finansowanie społecznościowe spotyka się $\mathrm{z}$ zainteresowaniem polskich sportowców. Jedna $\mathrm{z}$ platform crowdfundingowych zbierała w 2014 roku pieniądze dla łyżwiarza Zbigniewa Bródki, aby mógł doskonalić swoje umiejętności i wystartować w Igrzyskach Olimpijskich w Soczi, na których ostatecznie zdobył złoty medal (polakpotrafi.pl/dla-mediow, dostęp z dnia 16.03.2016).

Polacy, którzy chcą brać udział w finansowaniu społecznościowym (będąc podmiotami poszukującymi lub dostarczającymi kapitał), moga korzystać $z$ platform intermetowych zakładanych zarówno w Polsce, jak i w innych krajach. Największym polskim sukcesem jest zbiórka zorganizowana na platformie Kickstarter dla polskiego projektu oprogramowania Sher.ly, gdzie oczekiwany kapitał w wysokości 69 tys. USD zebrano już po sześciu dniach. Łącznie na projekt zebrano ponad 154 tys. USD od 896 osób (https://www.kickstarter.com dostep z dnia 12.03.2016). Poczatkowo większe projekty realizowane były głównie poza granicami kraju, jednak coraz częściej uznaniem cieszą się również krajowe portale. Według danych Komisji Europejskiej na koniec 2014 roku w Polsce istniało 16 platform finansowania społecznościowego (European Commission Crowdfunding, 2015). Warto jednak zaznaczyć, że oprócz liderów rynkowych, którzy funkcjonują na rynku od kilku lat, systematycznie powstają nowe platformy, inne z kolei kończą swoją działalność. Wśród portali funkcjonujących w Polsce występuja zarówno donacyjne, jak i biznesowe (tabela 5).

Przykładowe przedsięwzięcia zrealizowane $\mathrm{w}$ Polsce przy wykorzystaniu finansowania społecznościowego przedstawiono w tabeli 6.

W Polsce dominującą rolę odgrywają modele donacyjne i bonusowe (oparte na nagrodach), które stanowiły łącznie w 2014 roku ponad $90 \%$ wszystkich tego typu transakcji. Oznacza to, że zainteresowanie poszczególnymi modelami crowdfundingu w Polsce różni się od światowej tendencji. Pomimo rosnacego zainteresowania dominują przede wszystkim transakcje charyta- 
Tabela 5. Wybrane platformy crowdfundingowe w Polsce według modeli

\begin{tabular}{|c|c|c|}
\hline Model donacyjny & Model oparty na nagrodach & $\begin{array}{l}\text { Model inwestycyjny } \\
\text { i pożyczkowy }\end{array}$ \\
\hline $\begin{array}{l}\text { damnasport.pl } \\
\text { domore.pl } \\
\text { fanimani.pl } \\
\text { fundujesz.pl } \\
\text { ideowi.pl } \\
\text { megatotal.pl } \\
\text { mintu.me } \\
\text { odpalprojekt.pl } \\
\text { polakpotrafi } \\
\text { siepomaga.pl } \\
\text { stworzmista.pl } \\
\text { wspieramkulture.pl } \\
\text { wspolnyprojekt.pl } \\
\text { zamieszani.pl } \\
\text { zrzutka.pl }\end{array}$ & $\begin{array}{l}\text { ideowi.pl } \\
\text { megatotal.pl } \\
\text { odpalprojekt.pl } \\
\text { polakpotrafi } \\
\text { stworzmistrza.pl } \\
\text { wspieramkulture.pl } \\
\text { zamieszani.pl } \\
\text { zrzutka.pl }\end{array}$ & $\begin{array}{l}\text { beesfund.pl } \\
\text { crowdangels.pl } \\
\text { crowdcube.pl } \\
\text { ideowi.pl } \\
\text { mzurici.pl } \\
\text { wspolnicy.pl }\end{array}$ \\
\hline
\end{tabular}

Źródło: opracowanie własne na podstawie wymienionych stron.

Tabela 6. Wybrane przedsięwzięcia finansowane crowdfundingiem w Polsce w latach 2013-2015

\begin{tabular}{|l|l|l|l|l|l|}
\hline \multicolumn{1}{|c|}{ Firma } & \multicolumn{1}{|c|}{ Przedsięwzięcie } & \multicolumn{1}{c|}{ Platforma } & $\begin{array}{c}\text { Wartość } \\
\text { w PLN }\end{array}$ & $\begin{array}{c}\text { Model } \\
\text { crowdfundingu }\end{array}$ \\
\hline 1. & Inne beczki & Akcja browar & Beesfund.pl & 400000 & inwestycyjny \\
\hline 2. & Społeczność & $\begin{array}{l}\text { Wstęga pamięci - } \\
\text { pomnik u stóp Wawelu }\end{array}$ & Polakpotrafi.pl & 385615 & bonusowy \\
\hline 3. & Osoby prywatne & $\begin{array}{l}\text { Reaktywacja magazynu } \\
\text { Secret Service }\end{array}$ & Polakpotrafi.pl & 284110 & bonusowy \\
\hline 4. & In Pay & $\begin{array}{l}\text { Platforma obrotu } \\
\text { wirtualnym pieniądzem }\end{array}$ & Beesfund.pl & 200000 & inwestycyjny \\
\hline 5. & Allcool.pl Sp.z.o.o. & $\begin{array}{l}\text { Portal sprzedażowy piw } \\
\text { regionalnych }\end{array}$ & Crowdangels.pl & 76750 & inwestycyjny \\
\hline 6. & $\begin{array}{l}\text { Modular Analog } \\
\text { Research Station } \\
\text { M.A.R.S. }\end{array}$ & $\begin{array}{l}\text { Baza księżycowa pod } \\
\text { Krakowem }\end{array}$ & Polakpotrafi.pl & 69230 & donacyjny \\
\hline 7. & Osoba prywatna & $\begin{array}{l}\text { Zatrzymajmy w Polsce } \\
\text { polskich naukowców }\end{array}$ & Zrzutka.pl & 25937 & donacyjny \\
\hline 8. & $\begin{array}{l}\text { Chór Centrum } \\
\text { Myśli Jana Pawła II }\end{array}$ & $\begin{array}{l}\text { Płyta kołysankowa } \\
\text { Dobrej nocy i sza }\end{array}$ & Odpalprojekt.pl & 21903 & donacyjny \\
\hline
\end{tabular}

Źródło: opracowanie własne. 
Tabela 7. Liczba i wartość transakcji crowdfundingowych w Polsce w 2014 roku

\begin{tabular}{|l|c|c|c|}
\hline $\begin{array}{c}\text { Model } \\
\text { crowdfundingu }\end{array}$ & Liczba transakcji & $\begin{array}{c}\text { Lączna wartość } \\
\text { transakcji (w EUR) }\end{array}$ & $\begin{array}{c}\text { Udziat procentowy wartości } \\
\text { transakcji (\%) }\end{array}$ \\
\hline Inwestycyjny & 5 & 80000 & 1,95 \\
\hline Pożyczkowy & 2145 & 331000 & 8,05 \\
\hline Bonusowy & 398 & 1650000 & 40,14 \\
\hline Donacyjny & 386 & 2050000 & 49,87 \\
\hline Razem & 2934 & 4111000 & 100,00 \\
\hline
\end{tabular}

Źródło: opracowanie własne na podstawie European Commission Crowdfunding (2015).

tywne i społeczne, a nie pożyczkowe czy inwestycyjne, które mogą stać się realną alternatywą dla innych źródeł finansowania przedsiębiorstw. Model pożyczkowy stanowił niewiele ponad $8 \%$ wszystkich transakcji (tabela 7).

W Polsce w 2014 roku przeprowadzono tylko 5 transakcji opartych na modelu inwestycyjnym, które stanowiły niespełna $2 \%$ wszystkich transakcji. Spowodowane to było przede wszystkim brakiem jasnych przepisów prawnych dotyczących jego wykorzystania. $Z$ jednej strony brak odpowiedniego ustawodawstwa daje pewną swobodę możliwości wykorzystania. Z drugiej zaś - niesie ze sobą ryzyko, że podejmowane działania mogą zostać inaczej zinterpretowane przez instytucje nadzorujące (przede wszystkim Komisje Nadzoru Finansowego). Najnowsze zmiany w Kodeksie spółek handlowych, które mogą w jakimś stopniu ułatwić funkcjonowanie modelu inwestycyjnego, zostały wprowadzone w życie 1 kwietnia 2016 roku. Od tego dnia zaczął obowiązywać paragraf 2 art. 180, określający, iż możliwe będzie zbycie udziałów w systemie teleinformatycznym pod warunkiem wykorzystania wzorca umowy i zastosowania bezpiecznego podpisu elektronicznego (Kodeks spółek handlowych, art. 180, §2). Przed tą zmianą jakiekolwiek zbycie udziałów w spółce musiało być dokonane w formie pisemnej, a podpisy powinny być poświadczone przez notariusza, co właściwie wykluczało model crowdfundingu udziałowego. Szczegółowo zagadnienia związane ze zmianami w Kodeksie spółek handlowych opisali Wojdyło i Czarnecki (2015). Przepisy prawno-podatkowe związane $\mathrm{z}$ transakcjami finansowania społecznościowego w Polsce należą do najbardziej skompliko- wanych elementów tego rodzaju umów, co może zniechęcać potencjalnych inwestorów i pomysłodawców do podejmowania decyzji o zainteresowaniu finansowaniem społecznościowym (Kędzierska-Szczepaniak i Szczepaniak 2015).

\section{Zakończenie i wnioski}

Obserwując rozwój crowdfundingu, można stwierdzić, iż jest to jeden $z$ najbardziej dynamicznie rozwijających się sposobów prywatnego finansowania projektów biznesowych na wczesnym etapie rozwoju. Największym zainteresowaniem potencjalnych inwestorów i darczyńców na rynku amerykańskim cieszą się małe firmy $\mathrm{z}$ nowatorskimi pomysłami, które potrzebuja dofinansowania. Zdecydowanie trudniej pozyskać taki kapitał większym przedsiebiorstwom czy instytucjom badawczym (Crowdfunding Industry Report, 2013). Warto jednak brać pod uwagę to, że jest to stosunkowo nowatorska forma finansowania i wraz z jej rozwojem, może stać się atrakcyjną i dostępną formą pozyskania kapitału również dla dużych firm. Dla przedsiębiorstw znaczenie ma przede wszystkim crowdfunding pożyczkowy i inwestycyjny. Model pożyczkowy, jak przedstawiono $\mathrm{w}$ artykule, jest modelem dominującym wśród transakcji crowdfundingowych na świecie. Model inwestycyjny, idealny dla inwestorów indywidualnych, systematycznie się rozwija; obecnie szacuje się go na poziomie 500 mld USD.

W Polsce crowdfunding znajduje się na bardzo wczesnym etapie rozwoju. Obecnie dominują przede wszystkim zbiórki niezwiązane z działalnością gospodarczą, a mające znaczenie charytatywne. Zmiany dotyczące 
dostosowania przepisów prawnych, coraz większa świadomość rynku wśród potencjalnych inwestorów oraz działania podejmowane na poziomie nie tylko kraju, ale i Unii Europejskiej pozwalają przypuszczać, że będzie się on rozwijał. Działania te dotyczą przede wszystkim monitorowania rozwoju rynku finansowania społecznościowego wraz $\mathrm{z}$ analizą barier, na które mogą natknąć się uczestnicy rynku. Nadzór powinien dotyczyć głównie crowdfundingu inwestycyjnego i pożyczkowego, ponieważ to właśnie te formy mogą stać się alternatywa dla innych źródeł finansowania działalności przedsiębiorstw. Należy jednak pamiętać, aby w początkowej fazie rozwoju (a w takiej właśnie znajduje się crowdfunding w Unii Europejskiej) nie stawiać zbyt sztywnych ram i przepisów, które mogą spowodować zmniejszenie zainteresowania taką formą pozyskania kapitału.

\section{Przypisy}

1 Określenie crowdfunding powstało z połączenia dwóch słów: crowd, rozumianego jako tłum, i funding, jako fundowanie, finansowanie. $\mathrm{W}$ języku polskim przyjęło się tłumaczenie ,finansowanie społecznościowe", używane zarówno przez praktyków, jak i instytucje rządowe i pozarządowe, w tłumaczeniach tekstów Komisji Europejskiej. Nie oddaje ono w pełni znaczenia crowdfundingu, a czasem może wprowadzać w błąd, jednakże w niniejszym opracowaniu określenia „,crowdfunding" i ,finansowanie społecznościowe" będą traktowane zamiennie.

\section{Bibliografia}

Bedigian, L. (2014). Coke, Microsoft And 3 Other Big Companies That Have Used Crowdfunding. Benziga, Pozyskano z: http://www.benzinga. com/general/crowdsourcing/14/08/4802231/cokemicrosoft-and-3-other-big-companies-that-haveused-crowdfun (28.04.2016).

Belleflamme, P., Lambert, T. i Schwienbacher, A. (2014). Crowdfunding. Tapping the right crowd, Journal of Business Veturing, 29(5), http://dx.doi. org/10.1016/j.jbusvent.2013.07.003

Best, J. i Neiss, S. (2014) Crowdfunding: A Historical Perspectice. W: S. Dresner, Crowdfunding. $A$ Guide to Raising Capital on the Internet. New Jersey: John Wiley\&Sons.

Business Information Industry Association (2015), Crowdfunding: Peer-to-Peer Lending Expects to Triple in 2015. Pozyskano z: http://www.biia.com/ crowdfunding-peer-to-peer-lending-expect-totriple-in-2015 (24.02.2016).
Crowdfunding Industry Report (2013, 2015). Massolution.

Cunningham, W.M. (2012). The Jobs Act Crowdfunding for Small Businesses and Startups. New York: Apres.

Duliniec, A. (2001). Struktura i koszt kapitatu. Warszawa: Wydawnictwo Naukowe PWN.

Dziuba, D.T. (2012). Rozwój systemów crowdfundingu - modele, oczekiwania i uwarunkowania. Problemy Zarzadzania, 3(10), 83-103.

European Commission Crowdfunding (2015). Mapping EU markets and events study. Pozyskano z: http://ec.europa.eu/finance/general-policy/docs/ crowdfunding/20150930-crowdfunding-study_ en.pdf (12.03.2016).

Freedman, D.M. i Nutting, M.R. (2015). Equity Crowdfunding for Investors: A Guide to Risks, Returns, Regulations, Funding Portals, Due Diligence and Deal Terms. John Wiley and Sons.

Kappel, T. (2009). Ex ante crowdfunding and the recording industry: A model for the U.S. Loyola of Los Angeles Entertainment Law Review, 29(3), 375-385.

Kędzierska-Szczepaniak, A. i Szczepaniak, K. (2015). Podatkowe aspekty crowdfundingu. Zarzadzanie i Finanse, 13(4/1), 19-30.

Kleeman, F., Gunter Voss, G. i Rieder, K. (2008). Un(der)paid Innovators: The Commercial Utilization of Consumer Work Throuh Crowdsourcing, Science, Technology \& Innovation Studies, 4(1), 5-26.

Kodeks spółek handlowych, Dz.U. 2000 Nr 94 poz. 1037 z późn.zm.

Kozioł-Nadolna, K. (2015). Crowdfunding jako źródło finansowania innowacyjnych projektów. Zeszyty Naukowe Uniwersytetu Szczecińskiego $\mathrm{nr} 854$, Finanse, Rynki Finansowe i Ubezpieczenia nr 73, Wydawnictwo Naukowe Uniwersytetu Szczecinskiego, Szczecin, 671-683.

Król, K. (2011). Finansowanie spotecznościowe jako źródto finansowania przedsięwzięć w Polsce. Poznań: Wydawnictwo Crowdfunding.pl.

Kuppuswamy, V. i Bayus, B.L. (2013). Crowdfunding Creative Ideas: The Dynamics of Project Backers in Kickstarter, SSRN Electronic Journal, http:/ dx.doi.org/10.2139/ssrn.2234765

Lambert, T. i Schwienbacher, A. (2010). An Empirical Analysis of Crowdfunding. Pozyskano z: http:// ssrn.com/abstract $=1578175$ (08.12.2015).

Marom, D. (2012). A Framework for Political Crowdfunding. The Crowdfunding Revolution. Pozyskano z: http://www.danmarom.com/ post/35627344098/a-framework-for-political-crowdfunding-lessons (20.10.2015).

Mollick, E. i Kuppuswamy, V. (2014). After the Campaign: Outcomes of Crowdfunding; Social Science Research Network. Pozyskano z: http://papers. 
ssrn.com/sol3/papers.cfm?abstract_id $=2376997$ (13.03.2016), http://dx.doi.org/10.2139/ssrn.2376997

Murray, J. (2015). Equity Crowdfunding and Peer-to-peer lending in New Zaeland, JASSA The Finsia Journal of Applied Finance, 2. Pozyskano z: http://papers.ssrn.com/sol3/papers.cfm?abstract $\mathrm{id}=2595354(11.03 .2016)$

O'Gorman, C. i Terjesen, S. (2006). Financing the Celtic Tigress: Venture Financing and Informal Investment in Ireland. Venture Capital, 8(1), 69-88, http://dx.doi.org/10.1080/13691060500453742

Pais, I. (2015). I cinesi hanno scoperto il crowdfunding. Corriere de la serra, 31.03.2015. Pozyskano z: http://nuvola.corriere.it/2015/03/31/i-cinesihanno-scoperto-il-crowdfunding/?refresh ce-cp (20.02.2016).
Portal Kickstarter. Pozyskano z: https://www.kickstarter.com/projects/sherly/ (12.03.2016).

Portal Megatotal. Pozyskano z: http://www.megatotal.pl (20.02.2016).

Portal Polakpotrafi. Pozyskano z: http://polakpotrafi.pl/dla-mediow (16.03.2016).

Portal Wszystkonet. Pozyskano z: http://wszystko. net (12.03.2016).

Szyszko, I. (red.) (2000). Finanse przedsiębiorstwa. Warszawa: PWE.

Wojdyło, K. i Czarnecki, J. (2015). Nowe i planowane regulacje crowdfundingu inwestycyjnego. Pozyskano z: http:// www.wardynski.com.pl/biuletyn nowych technologii/2015-04/B03 PL Crowdfunding.pdf (2.02.2016). 